
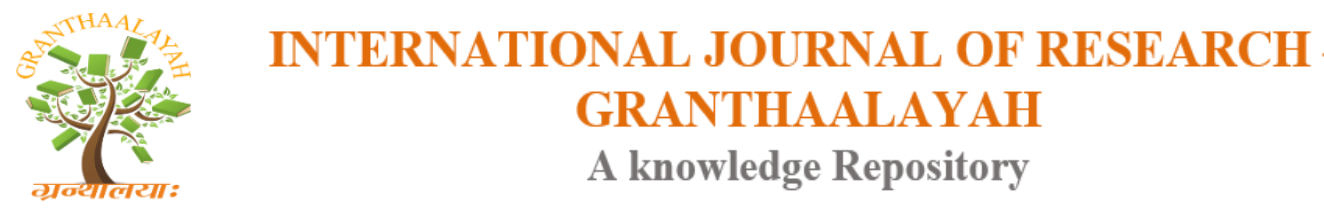

Science

\title{
AYURVEDIC MANAGEMENT OF GRIDHRASI W. S. R. SCIATICA: A CASE STUDY
}

\author{
Dr. Sagar Yashwant Doke ${ }^{* 1}$, Dr. Chandrakant N. Pathade ${ }^{2}$ \\ ${ }^{* 1}$ PG SCHOLAR, M.D. (Kayachikitsa), Late Kedari Redekar Ayurvedic Mahavidyalaya, \\ Tal. Gadhinglaj, Dist. Kolhapur.416502, India \\ ${ }^{2}$ M.D. (Kayachikitsa), HOD and Guide, Late Kedari Redekar Ayurvedic Mahavidyalaya, \\ Tal. Gadhinglaj, Dist. Kolhapur.416502, India
}

\begin{abstract}
Gridhrasi is one of the "Nanatmaja Vyadhis of vata". Improper sitting postures continuous and over exertion, jerking movements during travelling and sports produce structural abnormality in spinal cord. Vata is the prime dosha in the causation of Gridhrasi. The vitiated vata dosha get localized in the sphik, kati region. Occasionally it will be associated with kapha producing vata kaphaj Gridhrasi.

Gridhrasi is shoolpradhan vyadhi so it causes great discomfort to the patient. Pain primarily starts in the sphik region and in kati which can be related to lumbosacral region where sciatic nerve root starts. Pain later radiates through the posterior aspect of uru, janu, jangha, pada.

Gridrasi is cured by the help of shamana chikitsa. Hence in the case study of male patient of age 48 yrs presenting with cardinal clinical sign and symptoms of Gridhrasi are Ruka, Toda, Stambha and Muhu Spandana in the Sphika, Kati, Uru,Janu, Jangha and Pad in order and Sakthikshepanigraha that is restricted lifting of the leg.

Keywords: Gridhrasi; Shaman Chikitsa; Vata Dosha; Ayurvedic medication.

Cite This Article: Dr. Sagar Yashwant Doke, and Dr. Chandrakant N. Pathade. (2018). "AYURVEDIC MANAGEMENT OF GRIDHRASI W. S. R. SCIATICA: A CASE STUDY." International Journal of Research - Granthaalayah, 6(4), 340-344. https://doi.org/10.29121/granthaalayah.v6.i4.2018.1668.
\end{abstract}

\section{Introduction}

The symptoms of gridhrasi initially affect spick (buttock) as well as posterior aspect of kati (Lumbar) and then gradually radiates to posterior aspect of Uru (thigh), Janu (knee), Jangha (calf) and pada (foot). ${ }^{[1]}$ Acharya Sushruta views when two kandra in the leg gets affected with vata dosha, it limits the extension of leg, resulting in Gridhrasi. ${ }^{[2]}$ The symptoms are- Stambha (Stiffness), Thoda (Priking sensation), Ruk (pain), Muhuspandan (Tingling). In Vataja- Kaphaja there are types of Gridhrasi- Tandra, Gaurava (heaviness) and Arochaka. ${ }^{[3]}$ Sciatica is also known as sciatic neuritis, sciatic neuralgia or lumbar Radiculopathy when pain is felt going down the leg 
from the back. ${ }^{[4]}$ Sciatic is basically a symptom that arises due to compression or inflammation of sciatic nerve. ${ }^{[5]}$ On examination SLR test is positive. ${ }^{[6]}$ In general an estimated 5\%-10\% of patients with low back pain have sciatica. The annual prevalence of disc related sciatica in the general population is estimated at $2.2 \%{ }^{[7]}$

\section{Case report}

\section{History of personal illness}

A male patient aged 48 yrs presented with the complaints of vam kati te pad tal shool kati (lumbar) and then gradually radiates to posterior aspects of Uru (thigh), Janu (knee), Jangha (calf) and pada (foot) ubhay pad chimchimayan (tingling sensation), chakraman- kashata (difficulty in sitingstanding), padsuptata (tingling numbness), but from 20 days patient increase the severity of symptoms. The present case study is successful ayurvedic management of a case of Gridhrasi (Sciatica).

\section{Chief Complaints:-Duration}

1) Vaam kati te padatal shool (radiating pain from lumber, thigh, knee, calf, foot region) since 20 days,

2) Ubhay pad chimchimaya (tingling sensation) since 8 months,

3) Chakraman-kashatata (difficulty in walking) since 4 months,

4) Asane udishte kashtata (difficulty in sitting \& standing) since 4 months,

5) Padsuptata (tingling numbness) since 2 months.

\section{Astavidha Pariksha}

Nadi $($ pulse $)=82 / \mathrm{min}$.

Mala $($ stool $)=$ awastambha

Mutra (urine) $=3-4$ times in a day

Jeeva $($ tounge $)=$ Eshat saam

Agni $=$ prakrut

Shabda $($ speech $)=$ Normal

Akruti = Madhyama

Bala = Madhyama

Raktadaaba (B.P) $=130 / 80 \mathrm{~mm} / \mathrm{Hg}$.

On observation the power in patient in left lower limb was slightly lesser than right side. The gait of patient was like vulture and his walk very much frustrating and embracing to the patient. On table examinations his SLR test was positive in both legs $(\mathrm{L}>\mathrm{R})$ at $70^{\circ}$ in right and $40^{\circ}$ in left. The MRI findings showed straightening of normal lordosis, desiccative disc changes at L5-S1 level, mild diffuse disc bulge at L4-5 level causing thecal sac indentation, nerve compression. Lasegue's test was positive on bilateral side. 


\section{Materials and Methods}

Centre of study: Late Kedarki Redekar Ayurvedic Mahavidyalaya, Gadhinglaj Method of sampling \& study design: Simple randomized single case study.

\section{Materials}

\begin{tabular}{|l|l|l|l|}
\hline Dravya & Dose & Kala & Anupan \\
\hline Haritaki prayog ${ }^{[8]}$ & $\begin{array}{l}\text { 1. Haritaki churna - 3gm } \\
\text { 2. Eranda Tail- 10 ml }\end{array}$ & Nishakala & Luke warm water \\
\hline
\end{tabular}
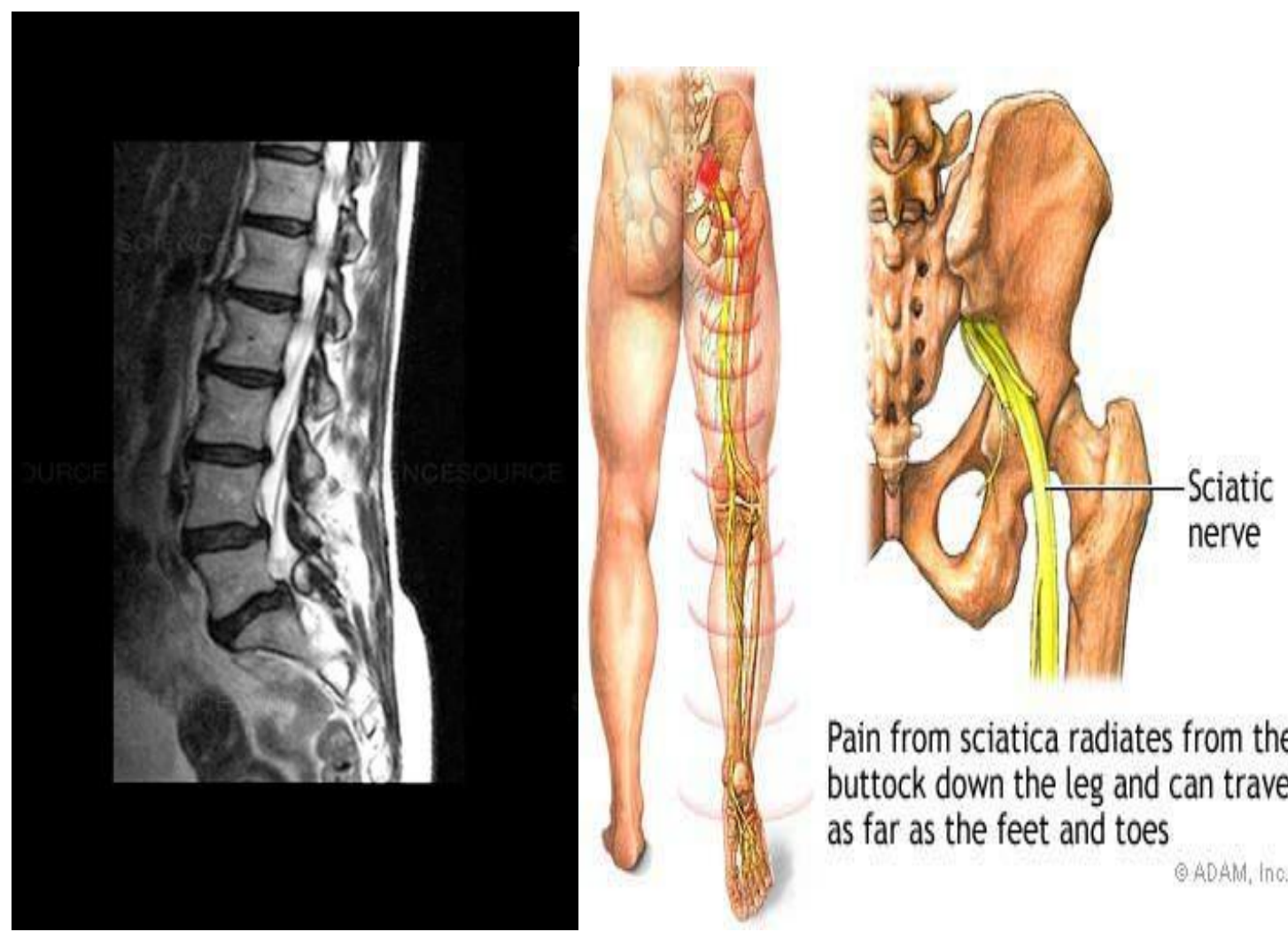

Pain from sciatica radiates from the buttock down the leg and can travel as far as the feet and toes

MRI image and anatomy of sciatic nerve

\section{Discussion}

\section{Hetu seven}

- Ahar- katu tikta kashaya rasatamak diet, ruksha, shit (cold), atisnigdha ahar.

- Vihar- Trvelling duty, over exertions, improper seating posture jerking movement during travelling, lack of proper sleep, vegadharana, indigestion.

- Samprati:

- Hetu seven > vata dosh Prokop > stratus stanvaigunya nirman (rukshata, parushata,kharata)

- $\quad>$ Rikta strotas vayupuran > spikpurva kati prushta jangha pad kramat ruja >

- grudhravat chalan $>$ Gridharasi

\section{Samprati-Ghatak}


- Dosha- vata dosha prakop

- Dushya - Majja, Asthi

- Srotas - Asthivaha, majjavaha

- Srotodusti - Sanchaya vrutti

- Udhbhavasthana - Asthi, Sandhi

- Vyaktasthana - Katipradesh, Uru, Janu, Jangha, Pad Pradeshi

\section{Samprapti bhanga}

The mode of action ${ }^{[9]}$ of haritaki prayog can be read as follows:

1) Eranda tail-

- Rasa: madhura, tikta, katu.

- Veerya:Ushana

- Vipaka: Madhura

- Guru: Snigdha, Teelshna, Guru, sukshama

Eranda is best vatahar dravya. Due to the properties like snigdha, ushna, guru, it pacifies mainly vata and kapha. Hence it will help to subside Ruksa, Sthambha, spandana, Gaurav. Due to which it helps to minimize the symptoms of gridhrasi.

2) Haritaki-

- Rasa: Pancha Rasa (Exept Lavana, main kashaya)

- Veerya: Ushna

- Vipaka: Madhura

- Guna: Laghu, Ruksha

Haritaki which helps of its properties subsides tridosha, which will minimize Gaurav, Tandra, Aruchi, Spandaa, Stambha. Hence it helps in reducing symptoms of gridharasi.

\section{Observation and Result}

The results observed after the treatment: Improvement in signs and symptoms of the patient. Relief was found in back pain, numbness and tingling sensation. Gait has improved. The patient has complete relief so he can sit comfortably.

\section{Walking distance}

Before treatment:-Patient had severe pain after walking $90 \mathrm{mts}$.

After treatment: - Patient could easily walk without pain about $180 \mathrm{mts}$.

\section{Walking time}

Before treatment: Patient took around 8 min. to walk 50 steps. After treatment: Patient took around 4 min. to walk 50 steps. No significant change was observed in MRI report.

\section{SLR test}

Before treatment: $40+$

After treatment: $70+$

\section{Conclusion}


Haritaki prayoga shows highly significant results in gridhrasi. From all this discussion it is cleared that Haritaki prayog is significantly effective in Gridhrasi. The entire treatment was accepted easily by the patients. There were no side effects noticed in any of the patients. The procedure was simple economical and can be done in OPD level gives relief to most of the patients, but still to avoid the reoccurrence of the disease and to break the Samprapti the patient may need to maintain their lifestyle.

\section{References}

[1] Vd. Bramhanad Tripathi: Charak Shamhita, Vatvydhi Chikitsa. Choukhamba Surbharti Prakashan, Varanasi: Pratisanskran 2005: Page No. 947.

[2] Vd. Ambikadatta Shasri: Sushrut Samhita: Chikitsastana Mahavatavyadhi: Chokhambha Sanskrit Prakashan: reprient 2009: page no. 43.

[3] Vd. Shivaprasad Sharma: Ashtang Sangraha: Vatavyadhi Nidan: Chokhambha Sanskrit Prakashan: $2^{\text {nd }}$ Edition 2008: Page no. 416.

[4] API Text Book of Medicine: Edition $7^{\text {th }}$, Page No.887, 1148.

[5] S. Das: A Mannual of Clinical Surgery $-7^{\text {th }}$ Edition, Examination of Peripheral Nerve Lesions: Page No. 97, Examination of spinal abnormalities: Page No. 225.

[6] Brain R. Walker: Nicki. R. Colledge: Stuart. H. Ralston: Davidson's Medicine, Neurological Disease: 22ndEdition, Reprint 2014: Page No. 1219.

[7] Younes M, Bejia I, Aguir Z, Letaif M, Hassen Zroer S, Touzi M, et al. Prevalence and risk factors of disc related sciatica in an urban population in Tunisia. Joint Bone Spine 2006; 73:538-42.

[8] Vd. Ambikadatta Shasri: Bhaishjya Ratnavali: Amavatachikitsa 29/14: Chokhambha Sanskrit Prakashan- $19^{\text {th }}$ Edition 2008: page no. 614.

[9] Vd. A.P. Deshpande, Vd. R.R. Jawalgekar, Vd. Subhash Ranade: Dravyaguna Vinyan part I, II.:Anamol Publication, Pune: $5^{\text {th }}$ edition Reprient Jan 2017: page no. 452, 646.

*Corresponding author.

E-mail address: drsagardoke@ gmail.com 